\title{
TRANSLEADQUAL Model: A Survey Instrument Developed for Transformational Leadership Style Conceptualized from SERVQUAL Model
}

\begin{abstract}
Anantha Raj A. Arokiasamy
Xiamen University Malaysia, Selangor, Malaysia

Keywords:

TRANSLEADQUAL, SERVQUAL, Transformational Leadership, Service Quality

\section{Received}

06 June 2019

Received in revised form

02 August 2019

Accepted

24 September 2019

Correspondence:

Anantharaj.arokiasamy@xmu.edu.my

ABSTRACT

When leaders nurture and identify individual talents in society, they are described as being transformational in nature. Some of the most popular leadership traits has been on transformational leadership, transactional leadership, servant leadership and most recently authentic leadership. Research on the transformational leadership has been one of the most frequently studied areas of investigation in the leadership spectrum. Although bout loads of articles have indeed explained in detail the transformational leadership style and the constructs involved but little has been said regarding the transformational leadership and service quality model together. Even though a lot of review has cited the instruments available as measures of transformational leadership quality, however, there is much evidence to support the gap conceptualizing the transformational leadership with service quality model. Hence the term TRANSLEADQUAL model was used in this conceptual paper to describe the development of this instrument used for gauging employee perceptions of the leadership service quality in private organizations. This paper employed the TRANSLEADQUAL conceptualized from the 22 -item instrument (called SERVQUAL) used for assessing customer perceptions of service quality in business organizations. As a generic model for many exceptional studies, SERVQUAL is truly valued and appreciated by many academicians and practitioners worldwide. The paper identified a truly novel concept and recommend survey instrument for transformational leadership style management conceptualized from the generic SERVQUAL Model.
\end{abstract}




\section{Introduction}

In the global economy, there is struggle to compete as more companies enter the markets and mergers continue at a faster rate than ever before. There is also a rise in ethical failures as organizations that once were successful thriving and on the cutting edge of their particular industry face a workforce that is less dedicated and committed (Minner, 2015). Today's leaders are unfocused, poor decision makers; while ambitious, they drive the bottom line, seek their interest or that of a select few at the top, they fail to set examples which results in the fact that they cannot sustain nor guarantee organizational success. Leadership is the pillar on which human assets plug into the organization mission; it is the worker who will drive organizational success. Leaders who ignore cultural factors among workers lose the benefits of those workers mental and collective value. Leaders at all levels can help usher out the old ways of thinking regarding a "one size fits all" approach and use cultural differences effectively to usher in a new paradigm that fosters participation, empowerment, learning and personal growth (VanderPal, 2014). Transformational leaders are part of a larger strategy that begins with their recruitment and selection, to effective mentoring and development under pre-selected organization leaders who take a long range view and commit the time and resources to build a strong leadership base at all levels and reward those who are truly transformational, while eliminating those who are not.

Transformational leadership is the choice of style for the future and while it may shift in terms of focus and direction, it is most desirable style that will focus on human capital, harnessing the collective knowledge and talent to place the organization on the cutting edge of competitive advantage (Saleem, 2015). Within the past three decades, global workforce diversity is the key driver for organization's human capital. With the dependence on labor and the global economy becoming stronger and more competitive, the ability to harness workers' talents, commitment and knowledge will separate those organizations that can survive from those which will succumb to cost and quality. Transformational leadership is reorganized as a preferred style for global operations that depend on cutting edge results and high performance from the workers (Uddin, Rahman, \& Howlader, 2014). Getting these results requires effective organizational development of its leadership program that provides a leadership pipeline within the organization that is sustainable. Distributing knowledge allows the organization to harness the collective creativity, skills and talents of the workforce, to empower them in becoming a partner with the business and to develop competencies that build competitive advantage. As partners in the organization, once followers were empowered, understood the vision and brought into that vision, they would enhance the actions to insure that it was carried out, knowing that ultimately it would provide value to all those who were affected (Top, Akdere, \& Tarcan, 2015). A key difference is in the ability of followers to identify with the organization rather than be rewarded or punished for their participation or non-participation. In this example of power sharing, organizations utilize human assets to bond with organizational goals and objectives.

Teams must be empowered by management to lead and direct the affairs of change at the lowest level and their style may or may not be predictable. Leaders who empower their workers and who lead others to lead themselves call the management style "super leadership" (Pradhan $\&$ Pradhan, 2015). The relationship between managers and workers has been reshaping for several decades. Manager-employee relations are now seen in terms of coaching, mentoring and facilitating. The division between the two roles at time may seem blurred but they are still 
defined with purpose. Employees are now in charge of tasks that once were reserved for management or specialists. This empowerment requires leaders who are able to foster a work environment and not fear encouraging employee participation in the workplace (Quintana, Park, \& Cabrera, 2015).

In an era of borderless world and globalization, service quality has been flaunted as the instrument which has helped organizations presently to gain competitive advantage over their rivals. It is often seen as a multi-dimensional construct in evaluating quality management (Buttle, 1996). Despite its importance and continued use of the SERVQUAL scale, many authors have expressed misperceptions over its dimensions. Nonetheless, its five generic dimensions and psychometric properties are well used in all service context. A review of the literature in the $21^{\text {st }}$ century highlighted the workplace quality that consists of tangible, reliability, responsiveness, assurance and empathy as a generic model that could well be used in multiple service sectors from education to banking to measure the expectation and perception's gap of customer's service quality (Chonody, Gabb, killian, \& Dunk-West, 2018). Without doubt, many researchers have modified the SERVQUAL dimensions to fit in with their research purpose and have applied this modified instrument successfully in various industries.

More importantly service quality is defined as the result of the comparison that customers make between expectations about a service and perception of the way the service was delivered. Although SERVQUAL has been subjected to many fundamental criticisms by researchers, its importance and popularity in service quality cannot be undermined. Many authors from the western countries have emphasized the fact that SERVQUAL and its dimensions differ greatly in terms of culture, countries and also industries (Hartwig \& Billert, 2018). Given the limited resources available to management, improvements in decision making and in particular customer satisfaction is utmost importance to organizations who are always striving to render high quality services. Due to this, SERVQUAL is still a robust scale for gauging service quality across service sectors. The SERVQUAL instrument appropriately used tangible, responsiveness, reliability, assurance and empathy in performing its daily tasks thus invoking customer satisfaction successfully. This paper intends to summarize and synergize the literature that provide arguments for and against the proposed TRANSLEADQUAL model in measuring transformational leadership quality based on the conceptualization of SERVQUAL model initiated by Parasuraman, Zeithaml and Berry (PZB) (1985).

\section{Literature Review}

\section{Transformational Leadership}

Transformational leadership has its roots with James Burn (1978) describing this leadership style as "Transformational Leadership is a process in which leaders and followers help each other to advance to a higher level of morale and motivation". After more than thirty years, research has validated Burns suggestion that transformational leadership is a partnership between the leader and the member, mutually supporting each other to a higher level of motivation. This interaction of engaging in each other's best interest has moral and ethical benefits that are inspirational for both parties, thus the term "transformational"; its nucleus is changed and has a changing effect. Transformational leaders do not totally discard the organizations hierarchical structure and programs but in fact may strengthen them by working within structure and policies to build and expand new ones and collapse old ones (Tse, Huang, \& Lam, 2013). 
Transformational leaders have self-confidence that allows them to feel satisfied with themselves and directs their efforts towards allowing them to lead from strength rather than from uncertainty or weakness. Assuming that the leader's confidence is altruistic, transformational leadership allows the leader to operate from a base of fixed principles rather than making up the rules as they go. Transformational leaders listen without being condescending because they care for the individuals whom they lead (Chow, 2014). They do not attempt to deceive their member; they are honest in their dealings and candid with their communications. This sense of integrity and openness is derived from a genuine sense of caring and desire to improve the followers. Transformational leaders are confident with themselves, weaving transformational style into their very being; they live the principles not simply talk them. As a result, they become comfortable with whom they are and tend not to seek power or control but seek to enable others to rise to if not surpass their own potential (Fernet, Trépanier, Austin, Gagné, \& Forest, 2015). Finally, effective leadership was once viewed as being able to impose one's will on the group rather than developing mutual respect with both the leader and follower nurturing innovation, moving forward with one purpose being bound by higher values of trust and courage. Transformational leaders not only trust their followers but are trusted by them as well. They are not afraid to share responsibilities or teach them higher skills that require the leader to delegate and empower followers, giving them important things to do for their development (Herlina, Basri, Kahar, \& Ihsan, 2015).

A unique aspect of transformational leadership is the emphasis of moral responsibility to others, which is closely aligned with integrity. Transformational leadership depends on honesty and integrity to build upon its main strength of believability from the follower. Integrity means always doing what is right and good, regardless of the immediate consequences. It is always doing the right thing without thought, motive or design. It draws parallel to being perfect or near perfect (Johnson, 2015). For business executives, it would mean being trustworthy and incorruptible and having a great deal of trust and confidence from the followers and customers. The ability of leaders to effectively practice transformational style can be instrumental in implementing strategies such as communications, team development, recruiting, training and culture building. In a study conducted by Bass and Avolio (1994), the study suggested that transformational leadership does have a positive impact on performance and individual development, while other leadership style measures were negatively related to business goals and objectives. Six key behaviors associated with transformational leadership that contribute to organizational effectiveness: 1) inspires others with a shared vision for the future, 2) leads by example, 3) encourages employees to work as teams, 4) sets high standards, 5) is respectful of individual feelings and differences and 6) is intellectually challenging. When these behaviors can be applied with consistency, the followers recognize that their interests are important and that the organization depends not only on their bodies but also on their minds and skills. They become motivated and to an extent, self-actualized as they realize their needs for recognition and appreciation as individuals come first.

Organizational leader may often take a for-the-moment transformational approach that rolls out new goals and visions to the workforce, by, first announcing there is a change in the way business is doing, to include participation and better communications; second, creating a separate division or department to design and push the vision down and through; third, using consultants as experts to gather information and ideas from the workforce; fourth, conducting 
special off site seminars to share with upper managers what the consultants have found and openly discuss new strategies and goal paths; finally, meeting in one year to see how things are going, only to find that it was nothing more than a great pep talk and cheerleading event. These approaches fail because the CEO and top leaders make no effort to change their behavior and become examples who are devoted to building commitment (Zhang, Ullrich, \& van Dick, 2015). Transformational leaders have more success in meeting organizational goals characterized by high optimism and self-efficacy. These transformational leaders achieve organizational goals through the concerted efforts of others; they know how to use human assets and how to motivate and direct them. Managers with a transformational style utilize the full range of behaviors such as individual consideration, intellectual stimulation, inspirational motivation and idealized behaviors (Zhang et al., 2015).

\section{SERVQUAL Model and Its Applications}

The PZB's model of service quality, namely SERVQUAL has been served as an important instrument in measuring service quality in the marketing literature. In 1988, they developed this model to measure customer's expectations and perceptions of service quality, which is a 22 item instrument based on five dimensions possessing different service quality attributes. PZB grouped the items into the following five distinct dimensions: tangibles (physical facilities, equipment and appearance of personnel), reliability (ability to perform the promised service dependably and accurately), responsiveness (willingness to help customers and provide prompt service), assurance (knowledge and courtesy of employees and ability to inspire trust and confidence) and empathy (caring, individualized attention the firm provides its customers) (Parasuraman et al., 1988, p. 6). The instrument is conceptualized as a gap between what the customers expect and their evaluations of the performance of a service (Parasuraman, Zeithaml, \& Berry, 1986, 1988; Parasuraman, Berry, \& Zeithaml, 1991; Zeithaml, Berry \& Parasuraman, 1993).

In other words, performance-to-expectations "gaps" on attributes that customers use to evaluate the quality of service form the theoretical foundation of SERVQUAL (Asubonteng, McClearly, \& Swan, 1996). PZB's conceptualization posits that expectations, coupled with perceived performance, lead to post purchase satisfaction. This effect is mediated through positive or negative disconfirmation between expectations and performance. As stated in the disconfirmation of expectation model, feelings of satisfaction arise when consumers compare their perceptions of a product performance to their expectations (Oliver, 1980; Spreng, Mackenzie, \& Olshavsky, 1996). In other words, disconfirmation is hypothesized to affect satisfaction, with positive disconfirmation leading to satisfaction and vice versa. In truth, PZB's model of service quality, namely SERVQUAL is a prominent model from marketing literature that has been applied in predicting and explaining consumers' satisfaction.

SERVQUAL is founded on the view that the customer's assessment of service quality is paramount. The service quality construct has been modified and simplified by US school of thought, namely Parasuraman, Zeithaml and Berry (PZB), where in 1985, they proposed that effective service quality should have ten specific dimensions, namely (1) reliability; (2) responsiveness; (3) competence; (4) access; (5) courtesy; (6) communication; (7) credibility; (8) security; (9) understanding/knowing the customer; (10) tangibles. However, in their 1988 work these components were collapsed into five dimensions, namely tangibles (physical facilities, equipment, and appearance of workers), reliability (ability to perform the promised 
service dependably and accurately), responsiveness (willingness to help customer and provide prompt service), assurance (knowledge and courtesy of workers and their abilities to inspire trust and confidence), and empathy (caring, individualized attention the organization provides its customers) (Ismail \& Mohd Yunan, 2016; Parasuraman, Berrym, \& Zeithaml 1991, 1994). Reliability, tangibles and responsiveness remained distinct, but the remaining seven components collapsed into two aggregate dimensions, assurance and empathy.

Specifically, SERVQUAL model has been used to measure service quality in a variety of service industries, including the higher education, healthcare sector, banking, fast food, telecommunications, retail chains, information systems, library services, car servicing, airline catering, computer services, ophthalmological services, mental health services, local government, recreational services, accounting firms, business-to-business channel partners (e.g., Arokiasamy, 2014; Arokiasamy \& Abdullah, 2013; Asghari \& Babu, 2018; Buttle, 1996; Chiang \& Perng, 2018; Hartwig \& Billert, 2018; Hisham, Sanyal, \& Ahmad, 2016; Ismail \& Mohd Yunan, 2016; Khattab, 2018; Ladhari, 2009; Leonnard, 2018; Markovic \& Raspor, 2010; Michael, Handrinos, Folinas, \& Rotsios, 2015; Muhammad Butt \& de Run, 2010; Neupane \& Devkota, 2017; Ok, Suy, Chhay, \& Choun, 2018; Ok \& Hengsadeekul, 2018; Pamatmat, Dominguez, Pamin, \& Daran, 2018; Patterson, Johnson, \& Spreng, 1997; Rehaman \& Husnain, 2018; Saghier, 2015; Shekarchizadeh, Rasli, \& Huam, 2011; Spreng \& Page, 2003; Syahir \& Hudrasyah, 2014; Yarimoglu, 2014).

\section{Transformational Leadership and Service Quality}

The literature on leadership and especially that derived from the empirical experience of leaders, has effectively taken us full circle. Leadership is now usually considered a process or a dynamic, rather than in terms of a position or hierarchy. Leading from within is just as important as leading from the front (Katou, 2015). Delegating power is often a more important aspect of leadership than accumulating it. Personal qualities and approaches are more important than just structures and lines of reporting. Motivating team members and celebrating their success and contribution to the organization's performance is the key to what is now recognized as being transformational leadership (Kao, Pai, Lin, \& Zhong, 2015).

Transformational leadership is a concept where anyone adopting the right approach can demonstrate leadership wherever they may be located in the organization. Such a leader is not a "born leaders" and does not need a specified list of traits, although the leadership talents which they do possess can be materially enhanced. Of course, not all leaders will be the same in terms of their personal style and approach as leadership is both an art and science. Indeed, there is now a comprehensive body of thought on transformational leadership which takes its place as a fully-fledged leadership concept (Paulienè, 2012). Moreover, it is a highly relevant concept for not-for-profit organizations experiencing a transition to becoming also a social enterprise. Leaders are now regarded as agents of change. The challenges are great for today's service organizations but the opportunities for those who master the science of leadership in the service sector are also tremendous. The act of leadership can be integrated into the marketing and operational strategies of any service organizations. In fact, today's servicedriven economy, you cannot expect to achieve leadership without service. The common denominator is the focus on assuming a leadership role either as a company in the marketplace or as an individual within the organization, regardless of formal authority or power (Kim \& Yoon, 2015). 
The concept of transformational leadership builds on ideas of strategy as perspective or culture and theories of leadership as a collective mind-set. The concept of transformational leadership suggests that the desired behaviours in today's service settings are collective leadership acts and that all organizations member share in protecting and preserving their organizations (Lan \& Chong, 2015). It takes the management practice of empowerment a step further in an attempt to overcome the disadvantages associated with power transfer and to capitalize fully on investments in higher labour and training costs. In service organizations aiming for service excellence, employees must have not only the authority to point out issues or to watch and wait for things to happen; they must also crave service excellence and regards it as their responsibility to be proactive to protect and preserve their organization and collectively shape their future working environment and organizational success. There is no doubt that, when an entire organization considers each encounter between an employer and a customer to be rich opportunity to improve customer service and build customer loyalty, a leadership mind-set is in place (Irshad, Hashmi, Arshad, \& Akram, 2014).

In this situation, every employee takes responsibility and pride in helping the organization reach a high level of service quality. Employees do this by carefully observing and communicating customer needs through organizational channels. Of course, this calls for a change in employee and managerial roles. It also calls for a reversal in the traditional relationship between service provider and customer. Instead of the employee just doing what the manager dictates, he or she must do what the customer wants and needs. This new view of roles and relationships empowers the entire organization to streamline its strategies and processes accurately and in a timely manner thus to achieve continuous service adaptation. This ability gives the organization a solid competitive advantage in the marketplace, where reactive behaviours are more common than proactive ones (Bauer, 2015).

One of a service organization's key performance indicators is the level of customer satisfaction it has obtained. Understanding and fulfilment of needs creates perceived value to customers and subsequently translates into customer satisfaction. In today's business environment, this is simply a prerequisite in the service industry. It is essential for the organization striving for service quality to expect and foresee changes and to use the power of a collective leadership mind-set to be able to go further and faster to obtain the organizations goals of growth profits and service quality (Ghasabeh, Soosay, \& Reaiche, 2015). The organization can obtain sustainable competitive advantages through service quality and leadership; in other words, it has to dare not to do what it has always done, both at the organizational level and on each employee's individual level of responsibility.

Standardized procedures and carefully laid-out processes ensure speed and accuracy of service. However, if an organization is going to use customer service as its primary weapon in the battle for market superiority, it must learn to use proven methods of success and simultaneously dare to be different (Poor, Poor, \& Darkhaneh, 2013). It must position itself differently and manage its human resources to foster initiative, helping behaviours and continuous improvement efforts. This is in line not only with marketing thoughts in the past two decades but also with the core of leadership science and human resources theory and research. In short, a transformational mind-set inspires each person to dare to use his or her brain to break market, organizational or personal barriers that are holding the organization back. 
In this way, the organization can be expected to obtain what can be called proactive service adaptation (Northouse, 2016).

Table 1

Recommended Questions for TRANSLEADQUAL Instrument

\begin{tabular}{|c|c|}
\hline Dimension & Question \\
\hline \multirow[t]{4}{*}{ Tangibles } & Physical appearance is visually appealing \\
\hline & All communication materials are working well \\
\hline & Equipment is adequate and meets industry standard \\
\hline & All personnel are observing neatness, cleanliness, well maintained, free of infection etc. \\
\hline \multirow[t]{4}{*}{ Reliability } & Meets promised time-frames for response \\
\hline & Sympathetic and reassuring when subordinates have problems \\
\hline & Service dependably and accurately performed \\
\hline & Keeps accurate record or information \\
\hline \multirow[t]{4}{*}{ Responsiveness } & Expected to tell subordinates or followers when the task will be performed \\
\hline & A willingness to help followers and provide prompt service \\
\hline & A willingness to take the time to explain thoroughly the situation faced by followers \\
\hline & Guide followers to achieve tasks promptly \\
\hline \multirow[t]{4}{*}{ Assurance } & Subordinates/followers should be trustworthy \\
\hline & Must feel safe when interacting with followers \\
\hline & Followers must treat with professionalism \\
\hline & Followers must convey trust and confidence when dealing with leaders \\
\hline \multirow[t]{4}{*}{ Empathy } & Leaders are expected to be caring, provide adequate support to do a task well \\
\hline & Must provide individualized attention if needed \\
\hline & Must have best interest at heart of followers \\
\hline & $\begin{array}{l}\text { Willingness to spend time and guidance needed to get the task done correctly and within the time- } \\
\text { frame required. }\end{array}$ \\
\hline
\end{tabular}

\section{Funding}

This work was funded by Xiamen University Malaysia Research Fund (Grant No. XMUMRF/2018-C2/ISEM/0002).

\section{References}

Arokiasamy, A. R. A. (2014). service quality on customer loyalty and intentions to switch in the airline industry in Malaysia. Australian Journal of Basic and applied Sciences, 8(6), 279-284.

Arokiasamy, A. R. A., \& Abdullah, A. G. (2013). Service quality and customer satisfaction in the cellular telecommunication service provider in Malaysia. Journal of Arts, Science \& Commerce, IV (2), 1-9.

Asghari, S., \& Babu, H. (2018). Service quality gap and its impact on the performance of Indian health insurance companies. Global Journal of Management and Business Research, 18(5), 18-41.

Asubonteng, P., McCleary, K. J., \& Swan, J. E. (1996). SERVQUAL revisited: A critical review of service quality. Journal of Services Marketing, 10(6), 62-81.

Bass, B. M., \& Avolio, B. J. (Eds.). (1994). Improving organizational effectiveness through transformational leadership. Thousand Oaks, CA: Sage Publications.

Bauer, D. (2015). Successful leadership behaviours in Slovak organizations' environment - an introduction to Slovak implicit leadership theories based on GLOBE study findings. Journal for East European Management Studies, 20(1), 9-35.

Burns, J. M. (1978). Leadership. New York: Harper \& Row, Publishers, Inc.

Buttle, F. (1996). SERVQUAL: Review, critique, research agenda. European Journal of Marketing, 30 (1), 8-32.

Chiang, T. Y., \& Perng, Y. H. (2018). A new model to improve service quality in the property management industry. International Journal of Strategic Property Management, 22(5), 436-446.

Chonody, J. M., Gabb, J., killian, M., \& Dunk-West, P. (2018). Measuring relationship quality in an international study: Exploratory and confirmatory factor validity. Research on Social Work Practice, 28(8), 920-930.

Chow, P. (2014). Does transformational leadership matter during organizational change? European Journal of Sustainable Development, 3(3), 49-62.

Fernet, C., Trépanier, S., Austin, S., Gagné, M., \& Forest, J. (2015). Transformational leadership and optimal functioning at work: On the mediating role of employees' perceived job characteristics and motivation. Work and Stress. An International Journal of Work, Health and Organization, 29, 11-31. 
Ghasabeh, M. S., Soosay, C., \& Reaiche, C. (2015). The emerging role of transformational leadership. The Journal of Developing Areas, 49(6), 459-467.

Hartwig, K. \& Billert, M. S. (2018). Measuring service quality: A systematic literature review. Paper Presented at European Conference on Information Systems (ECIS). Portsmouth, UK.

Herlina, B., Basri, M., Kahar, F., \& Ihsan, A. (2015). Transformational leadership influence toward high school teacher performance in Wajo Regency. International Journal of Academic Research, 7(1), 170-175.

Hisham, M. W., Sanyal, S., \& Ahmad, M. (2016). The impact of service quality on customer satisfaction: A study on selected retail stores in India. International Review of Management and Marketing, 6(4), 851-856.

Irshad, R., Hashmi, M. S., Arshad, S., \& Akram, S. (2014). Does managers' emotional intelligence impact employees' performance? Assessing mediating role of transformational leadership. Journal of Basic and Applied Scientific Research, 4, 612 .

Ismail, A., \& Mohd Yunan, Y. S. (2016). Service quality as a predictor of customer satisfaction and customer loyalty. LogForum, 12(4), 269-283.

Johnson, J. (2015). Transformational leadership in long term care in Inverness, Scotland. Kentucky Nurse, 63(2), 8-9.

Kao, P. J., Pai, P. Y., Lin, T. L., \& Zhong, J. Y. (2015). How transformational leadership fuels employees' service innovation behavior. The Service Industries Journal, 35, 448-466.

Katou, A. A. (2015). Transformational leadership and organizational performance. Employee Relations, 37, 329-353.

Khattab, F. (2018). Developing a service quality model for private higher education institutions in Lebanon. Journal of Management and Marketing Review, 3(1), 24-33.

Kim, S., \& Yoon, G. (2015). An innovation-driven culture in local government. Do senior manager's transformational leadership and the climate for creativity matter? Public Personnel Management, 44(2), 147-168.

Ladhari, R. (2009). A review of twenty years of SERVQUAL research. International journal of quality and service sciences, 1(2), $172-198$.

Lan, X. M., \& Chong, W. Y. (2015). The mediating role of psychological empowerment between transformational leadership and employee work attitudes. Procedia Social and Behavioral Sciences, 172(27), 184-191.

Leonnard (2018). The performance of SERVQUAL to measure service quality in private university. Journal on Efficiency and Responsibility in Education and Science, 11(1), 16-21.

Markovic, S., \& Raspor, S. (2010). Measuring perceived service quality using SERVQUAL: a case study of the Croatian hotel industry. Management, University of Primorska, Faculty of Management Koper, 5(3), 195-209.

Michael, C., Handrinos, M. C., Folinas, D., \& Rotsios, K. (2015). Using the SERVQUAL model to evaluate the quality of services for a farm school store. Journal of Marketing and Consumer Behavior in Emerging Markets, 1(1), 62-74.

Minner, W. (2015). Leading global organizations. Journal of Management Policy and Practice, 16(2), 122-126.

Muhammad Butt, M., \& de Run, E. C. (2010). Private healthcare quality: Applying a SERVQUAL model. International Journal of Health Care Quality Assurance, 23(7), 658-673.

Neupane, R., \& Devkota, M. (2017). Evaluation of the impacts of service quality dimensions on patient/customer satisfaction: A study of private hospitals in Nepal. International Journal of Social Sciences and Management, 4(3), 65-176.

Northouse, P. G. (2016). Leadership: Theory and practice (7th ed.). Los Angeles, CA: SAGE.

Ok, S., \& Hengsadeekul, T. (2018). Customer satisfaction on service quality of bus transport: a survey of passengers from Phnom Penh to Poipet in Cambodia. Journal of Social Science Studies, 5(2), 114-131.

Ok, S., Suy, R., Chhay, L, \& Choun, C. (2018). Customer satisfaction and service quality in the marketing practice: study on literature review. Asian Themes in Social Sciences Research, 1(1), 21-27.

Oliver, R. L. (1980). A Cognitive Model of the Antecedents and consequences of satisfaction decisions. Journal of Marketing Research, 17(4), 460-69.

Pamatmat, F, V., Dominguez, L. L., Pamin, C. D., \& Daran, A. M. (2018). Service quality dimensions of a Philippine state university and students' satisfaction: Bridging gaps to excellence. International Journal of Advance Research, 6(7), 673-681.

Parasuraman, A., Zeithaml, V., \& Berry, L. L. (1985). A conceptual model of service quality and its implications for future research. Journal of Marketing, 49(Autumn), 41-50.

Parasuraman, A., Zeithaml, V., \& Berry, L. L. (1986). SERVQUAL: A multiple-item scale for measuring customer perceptions of service quality. Report, 86-108, Marketing Science Institute, Cambridge, MA.

Parasuraman, A., Zeithaml, V., \& Berry, L. L. (1988). SERVQUAL: A multiple-item scale for measuring consumer perceptions of service quality. Journal of Retailing, 64(Spring), 12-40.

Parasuraman, A., Zeithaml, V., \& Berry, L. L. (1991). Refinement and reassessment of the SERVQUAL scale. Journal of Retailing, 67(4), 420-50. 
Parasuraman, A., Zeithaml, V., \& Berry, L. L. (1994). Reassessment of expectations as a comparison standard in measuring service quality: Implications for future research. Journal of Marketing, 58, 111-124.

Patterson, P. G., Johnson, L. W., \& Spreng, R. A. (1997). Modeling the determinants of customer satisfaction for business-tobusiness professional service. Journal of the Academy of Marketing Science, 25(1), 4-17.

Paulienè, R. (2012). Transforming leadership styles and knowledge sharing in a multicultural context. Business. Management and Education, 10, 91-109.

Poor, M. H., Poor, M. A., \& Darkhaneh, M. A. (2013). The quality of service and its importance in service organizations. Arabian Journal of Business and Management Review (OMAN Chapter), 3(3), 34-37.

Pradhan, S., \& Pradhan, R. K. (2015). An empirical investigation of relationship among transformational leadership, affective organizational commitment, and contextual performance. Vision, 19(3), 227-235.

Quintana, T. A., Park, S., \& Cabrera, Y. A. (2015). Assessing the effects of leadership styles on employees' outcomes in international luxury hotels. Journal of Business Ethics, 129(2), 469-489.

Rehaman, B., \& Husnain, M. (2018). The impact of service quality dimensions on patient satisfaction in the private healthcare industry in Pakistan. Journal of Hospital and Medical Management, 4(1), 1-8.

Saghier, N. M. E. (2015). Managing service quality: Dimensions of service quality. International Journal of African and Asian Studies, 9, 56-64.

Saleem, H. (2015). The impact of leadership styles on job satisfaction and mediating role of perceived organizational politics. Procedia - Social and Behavioral Sciences, 172(27), 563-569.

Shekarchizadeh, A., Rasli, A., \& Huam, H. T. (2011). SERVQUAL in Malaysian universities: perspectives of international students. Business Process Management Journal, 17(1), $67-81$.

Spreng, R. A., \& Page, Jr. T. J. (2003). A test of alternative measures of disconfirmation. Decision Sciences, 34(1), 31-62.

Spreng, R. A., MacKenzie, S. B., \& Olshavsky, R. W. (1996). A reexamination of the determinants of consumer satisfaction. Journal of Marketing, 60(3), 15-32.

Syahir, F., \& Hudrasyah, H. (2014). The influence of service quality dimensions on customer satisfaction and customer loyalty in Pt. Jne North Bandung area. Journal of Business and Management, 3(5), 546-556.

Top, M., Akdere, M., \& Tarcan, M. (2015). Examining transformational leadership, job satisfaction, organizational commitment, and organizational trust in Turkish hospitals: Public servants versus private employees. International Journal of Human Resource Management, 26, 1259-1282.

Tse, H. H. M., Huang, X., \& Lam, W. (2013). Why does transformational leadership matter for employee turnover? A multi-foci social exchange perspective. Leadership Quarterly, 24(5) 763-776.

Uddin, M. A., Rahman, M. S., \& Howlader, M. H. R. (2014). Exploring the relationships among transformational leadership, deviate workplace behavior, and job performance: An empirical study. ABAC Journal, 34(1), 1-12.

VanderPal, G. (2014). Global leadership, IQ and global quotient. Journal of Management Policy and Practice, 15(5), 120-134.

Yarimoglu, E. K. (2014). A review on dimensions of service quality models. Journal of Marketing Management, 2(2), 79-93.

Zeithaml, V., Berry, L. L., \& Parasuraman, A. (1993). The nature and determinants of customer expectations of service. Journal of the Academy of Marketing Science, 21(I), 1-12.

Zhang, X., Li, N., Ullrich, J., \& van Dick, R. (2015). Getting everyone on board: The effect of differentiated transformational leadership by CEOs on top management team effectiveness and leader-rated firm performance. Journal of Management, 41(7), $1898-1933$. 